\title{
Estimating the nursing staff required in a new hospital
}

\author{
Ana Cristina Rossetti ${ }^{1}$ \\ Raquel Rapone Gaidzinski²
}

\begin{abstract}
Opening a new hospital poses a complex and consequential set of challenges. One of these challenges is to estimate the nursing staff. The aim of this article is to report the entire process adopted to estimate the required nursing staff for a new Hospital in Brazil. The nursing staff was projected according to the Brazilian Federal Nursing Council (Cofen). We applied an equation to estimate nursing staff and compared the results with two other existing hospitals. A significant difference $(p<0.05)$ was observed when comparing the Nurse-License Practice Nurse ratio recommended by Cofen between the new Hospital and other hospitals. This statistical difference is mostly due to reduced nurse staff in intensive care units. Almost one year after the hospital opened its doors, it is necessary to review nursing staff hours with the real information to reinforce the expenditure on these personnel and to evaluate the decisions made so far.
\end{abstract}

Descriptors: Personnel Management; Hospital Administration; Nursing Staff, Hospital.

${ }^{1}$ RN, Master's Student, Escola de Enfermagem, Universidade de São Paulo, SP, Brazil. E-mail: rossetti@einstein.br. 2 RN, Ph.D. in Nursing, Full Professor, Escola de Enfermagem, Universidade de São Paulo, SP, Brazil. E-mail: raqui@usp.br.

Corresponding Author: Ana Cristina Rossetti Hospital Israelita Albert Einstein

Av. Albert Einstein, 627

Bairro: Morumbi

CEP: 06753-450, São Paulo, SP, Brasil

E-mail: ana_rossetti@hotmail.com 


\title{
Estimativa do quadro de pessoal de enfermagem em um novo hospital
}

Abrir um novo hospital é desafio complexo e passível de consequências. Um desses desafios é estimar o quadro de pessoal de enfermagem. O objetivo deste artigo foi relatar o processo adotado para estimar o quadro de pessoal de enfermagem em um novo hospital, no Brasil. O quadro de enfermagem desse hospital foi projetado segundo o método recomendado pelo Conselho Federal de Enfermagem (COFEN). Os resultados foram comparados com o dimensionamento de dois hospitais semelhantes, já em funcionamento. Houve diferença significativa $(p<0,05)$ quando se comparou a relação enfermeiro/técnico/auxiliar de enfermagem, recomendada pelo COFEN, nos três hospitais. Essa diferença, estatisticamente significante, foi decorrente do reduzido quadro de enfermeiros, nas unidades de terapia intensiva. Após um ano de sua inauguração, foi necessário rever o quadro de enfermagem projetado, considerando as informações reais para justificar o custo do pessoal de enfermagem e avaliar as decisões tomadas até o momento.

Descritores: Administração de Recursos Humanos; Administração Hospitalar; Recursos Humanos de Enfermagem no Hospital.

\section{Estimación de personal de enfermería en un hospital nuevo}

\begin{abstract}
Abrir un nuevo hospital es un asunto complejo y sujeto a consecuencias. Uno de los desafíos es estimar el personal de enfermería. El objetivo de este trabajo es describir el proceso adoptado para estimar el personal de enfermería en un hospital nuevo en Brasil. El número de enfermeras del nuevo Hospital fue calculado de acuerdo con el método recomendado por el Consejo Federal de Enfermería de Brasil (Cofen). Los resultados se compararon con dos hospitales similares, ya en funcionamiento. Se encontró una diferencia significativa $(p<0,05)$ con respecto a la relación entre enfermeras y auxiliares de enfermería recomendado por Cofen en los tres hospitales. Esta diferencia estadística se debe principalmente al menor número de enfermeras en las unidades de cuidados intensivos. Casi dos años después de su apertura es necesario revisar el número de enfermeras teniendo en cuenta la información real para justificar el coste de personal y evaluar las decisiones adoptadas hasta el momento.
\end{abstract}

Descriptores: Administración de Personal; Administración Hospitalaria; Personal de Enfermería en Hospital.

\section{Introduction}

Opening a new hospital is a major, complex, and consequential challenge. A multitude of decisions have to be made to ensure that affordable, safe, appropriate and high quality services are provided to patients ${ }^{(1)}$.

One important issue in any hospital is the nursing staff. It is known that few and low levels of registered nurse (RN) staff are associated with poor patient outcomes, such as pneumonia, urinary tract infections, lengthy stays, upper gastrointestinal bleeding, shock and high rates of general infections ${ }^{(2-10)}$. On average, in the US, the cost of nursing staff represents $63 \%$ of a hospital's labor costs(11).

In some countries like Brazil and others in South America, the licensed practical nurse (LPN) is allowed to assist patients under RN supervision. This assistance includes basic tasks, ranging from cleaning and feeding patients to administration of all kinds of medications, including intravenous ones. Therefore, the number of LPNs taking care of patients in these countries can sometimes be higher than the number of RNs. In these 
countries, RNs supervise the LPNs, assess patient needs, develop patient care plans, and perform highly skilled procedures like catheter insertion and enteral feeding tube placement. In 1996, an American institute issued a report that recognized the importance of determining the appropriate RN-patient ratio and the distribution of RNs and LPNs according to their skills to ensure that patients receive high quality health care(12). In the current study, the nursing staff consists of RNs and LPN.

The nursing staff can be measured as nursing hours per patient or as RN-patient ${ }^{(13-14)}$ and LPN-patient ratios. We have found some descriptions of how to estimate the nursing staff(15-18). In those, we did find that the nursing staff is estimated based on the relation between the hours of care per patient and the nursing hours available. The patient workload must be considered(16,18-19). In addition, other variables are also taken into consideration, such as leaves of absence(15-18), absences and vacations(16-18). One study ${ }^{(15)}$ also considers the various peaks of patients in each unit throughout the day.

To establish the necessary nursing staff, it is also required to examine the nursing service, the patient population and the hospital facility itself ${ }^{(17)}$. Only with this information in hand is it possible to estimate the budget and justify the necessary investment to be made in nursing staff(16-17). All this information may be useful when renovating the nursing staff of a hospital that already exists. However, how should the appropriate nursing staff for a new hospital be estimated? In this article, we report the whole process we adopted for estimating the required nursing staff of a new hospital in Sao Paulo, Brazil. We believe that our account will be useful to other health care managers and administrators who are involved in similar tasks, regardless of the hospital size and location.

\section{Methods}

This study was developed to project the required nursing staff for inpatient care units for a new Hospital $(\mathrm{MDH})$ in Sao Paulo, Brazil.

The nursing staff of MDH was projected by considering the recommendations of the Brazilian Federal Nursing Council (Cofen) ${ }^{(17)}$ methodology and benchmarking to two similar public hospitals.

To determine how many RNs and LPNs were necessary in the inpatient care units, we considered the nursing services, the patient population and the hospital facility itself. Since the MDH was not yet open, some information had to be decided on or estimated based on the projections we made, such as the distribution of beds in each unit, the occupation rate, the patient workload and the nursing absence rates.

First, the board decided how the hospital would be structured and its organizational chart. We adopted a multidisciplinary approach for patient care and decided on the administrative support needed to assist patients and their families. We also had to take into account the resources available in the region and the demographics of the population that we expected would be using the hospital.

Currently, the MDH is a public hospital of intermediate complexity, managed by a public-private partnership, with 240 beds. Inpatient services include obstetrics, medical-surgical treatment, psychiatry, pediatrics, and adult, pediatric, and newborn intensive care. The hospital has no walk-in clinic; and it only admits patients through its Emergency Unit.

The MDH is located in a four-floor building. The inpatient units are distributed over two of these floors. On the first floor, the adult, pediatric, and newborn intensive care units are located. All necessary medications are delivered to these units by a central pharmacy that is located on the underground floor. Another smaller pharmacy is located on the first floor and is responsible for serving the intensive care units.

In the neighborhood where the $\mathrm{MDH}$ is located, there are 13 outpatient facilities (two of them for patients with psychological problems) and 33 facilities for patients with chronic diseases ${ }^{(20)}$.

The annual budget established by the state government to be invested in a new hospital is based on benchmarking with other similar institutions. The annual productivity goal of any public hospital in Brazil of this type is evaluated every 3 months. When the goal is not achieved, the institution receives only $90 \%$ of the projected annual budget.

To better know the population we expected that was going to use our hospital, we searched for information in the areas surrounding $\mathrm{MDH}$. We also collected information about other health care facilities located in the area and asked whether they were prepared and equipped to assist the population.

The population living in the area around $\mathrm{MDH}$ had 537,469 inhabitants, of whom $37.4 \%$ were under 19 years and $5.7 \%$ over 60 years ${ }^{(21)}$. The population growth in the area has been 2.6 times more than the rates in the county. It is a poor region in which $26 \%$ of the population lives in slums. In 1996, the UN considered the MDH neighborhood (known as Jardim Angela) as the 
most violent area in the world ${ }^{(22)}$. Currently, murder is the third cause of death in the area, following ischemic heart disease ${ }^{(21)}$. With this information in mind, we estimated the nursing staff according to the Cofen recommendation, in three phases. In the first phase, we estimated the occupation rates per unit using the population information and health facilities around $\mathrm{MDH}$. Next, we estimated the average patient workload rates per unit, according to the Patient Classification System recommended by the Cofen ${ }^{(17)}$ (Table 1 ).

Table 1 - Expected occupation and workload rates in MDH units. The workload is expressed in hours per day and is based on the expected occupation rate. The number of beds is in parentheses

\begin{tabular}{|c|c|c|c|c|c|c|}
\hline \multirow[b]{2}{*}{ Unit } & \multirow[b]{2}{*}{ Beds } & \multirow{2}{*}{$\begin{array}{c}\text { Occupation rate } \\
\text { expected }\end{array}$} & \multicolumn{4}{|c|}{ Workload expected } \\
\hline & & & $\begin{array}{c}\text { Intensive Care } \\
(17.9 \mathrm{~h})\end{array}$ & $\begin{array}{c}\text { Step-down Care } \\
(9.4 \mathrm{~h})\end{array}$ & $\begin{array}{c}\text { Intermediate Care } \\
(5.6 \mathrm{~h})\end{array}$ & $\begin{array}{c}\text { Minimum Care } \\
(3.8 \mathrm{~h})\end{array}$ \\
\hline Medical Surgical & 82 & $85 \%(70)$ & - & - & $140(25)$ & $171(45)$ \\
\hline Obstetrics & 50 & $90 \%(45)$ & - & - & $140(25)$ & $76(20)$ \\
\hline Pediatric & 40 & $90 \%(36)$ & - & - & $201.6(36)$ & - \\
\hline Adult Intensive Care & 20 & $100 \%(20)$ & $179(10)$ & $94(10)$ & - & - \\
\hline Pediatric Intensiva Care & 10 & $100 \%(10)$ & $89.5(5)$ & $47(5)$ & - & - \\
\hline Neonatal Intensive Care & 26 & $80 \%(21)$ & $89.5(5)$ & $84.6(9)$ & $39.2(7)$ & - \\
\hline
\end{tabular}

To estimate the average workload of the nursing staff, we applied the following equation, adapted from Cofen(17):

$$
\bar{W}=\sum \overline{n_{j}} \times \overline{h_{j}}
$$

Where:

$\bar{W}$ is the average nursing workload;

$\bar{n}_{j}$ is the average number of patients per type of care $(j)$; and of care $(j)$

$\bar{h}_{j}$ is the average time expressed in hours per type

In the second phase, we calculated the RN and LPN staff, taking into account that:

- The nursing staff to look after Intensive care patients should be $52 \%$ RNs and $48 \%$ LPNs;

- The nursing staff to look after Step-down care patients should be $42 \%$ RNs and $58 \%$ LPNs;

- The nursing staff to look after Intermediate and Minimum care patients should be $33 \%$ RNs and $67 \%$ LPNs;

- The nursing staff works 36 hours a week in shifts of six hours each. The whole time equivalent (WTE) is 36 hours;

- One month has, on average, 4.2 weeks;

- The units function 24 hours per day, 7 days per week;

- The absence rates used for paid or unpaid leaves, such as vacations, sickness, and maternity was 1.15 ;
Taking all of these factors into account, we applied the following equation adapted from $\operatorname{Cofen}^{(17)}$ :

$$
Q_{k}=P_{k} \% \frac{\bar{W} \times 7}{W T E} \times 1.15
$$

Where:

$Q_{k}$ is the final nursing staff number;

$P_{k} \%$ is the percentage of RNs and LPNs;

$\bar{W}$ is the average workload expected; and

WTE is the whole time equivalent

In the last phase, we compared the nursing staff we estimated according to the Cofen ${ }^{(17)}$ recommendation with the nursing staff of two other similar public hospitals. Because the nursing staff could not be compared based on the number of beds, as each hospital had its own number of beds, an indicator had to be created by dividing the number of RNs and LPNs by the number of beds in each unit, in each hospital To compare the results, this indicator was multiplied by the number of beds at MDH. Finally, we adjusted the percentage of RNs and LPNs to the MDH budget and submitted it to the $\mathrm{MDH}$ board.

In the statistical analysis, Pearson's chi-square test was performed to compare the proportions between RNs and LPNs staff of the Cofen recommendation and the three hospitals. P-values $<0.05$ were considered statistically significant. 


\section{Results}

The nursing staff that was adjusted and approved by the $\mathrm{MDH}$ board, compared to the nursing staff recommended by Cofen ${ }^{(17)}$ and to the benchmarking is shown in Table 2. By resolution, the $\mathrm{MDH}$ board approved 44 fewer RNs and 47 more LPNs than initially recommended. As compared to Bench 1, MDH approved 20.1 more RNs and 23.6 fewer

LPNs. As compared to Bench 2, MDH approved 24.5 more RNs and 29 fewer LPNs.

Table 2 - Nursing staff approved by MDH compared with Cofen recommendation and benchmarking. The data are expressed in hours per month. The numbers in parentheses relate to the numbers of RN to be hired

\begin{tabular}{|c|c|c|c|c|c|}
\hline Unit & Nursing Staff & Cofen Recomended & MDH Approved & Bench 1 & Bench 2 \\
\hline \multirow[t]{2}{*}{ Medical Surgical } & $\mathrm{RN}$ & $3,477.6(23)$ & $2,872.8(19)$ & $1,693.4(11.2)$ & $2,011(13.3)$ \\
\hline & LPN & $7,106.4(47)$ & $8,164.8(54)$ & $8,820(58.3)$ & $10,085.9(66.7)$ \\
\hline \multirow[t]{2}{*}{ Obstetric } & $\mathrm{RN}$ & $2,419.2(16)$ & $2,116.8(14)$ & $1,428.8(9.5)$ & $952.6(6.3)$ \\
\hline & LPN & $4,838.4(32)$ & $5,443.2(36)$ & $5,729.7(37.9)$ & $6,804(45)$ \\
\hline \multirow[t]{2}{*}{ Pediatric } & $\mathrm{RN}$ & $2,268(15)$ & $2,419.2(16)$ & $1,143.1(7.6)$ & $1,306.4(8.6)$ \\
\hline & LPN & $4,536(30)$ & $4,536(30)$ & $4,870.2(32.2)$ & $5,443.2(36)$ \\
\hline \multirow[t]{2}{*}{ Adult Intensive Care } & $\mathrm{RN}$ & $4,536(30)$ & $1,512(10)$ & $1,874.9(12.4)$ & 1,209.6 (8) \\
\hline & LPN & $4,687.2(31)$ & $6,652.8(44)$ & $7,908.9(52.3)$ & $6,652.8(44)$ \\
\hline \multirow[t]{2}{*}{ Pediatric Intensive Care } & $\mathrm{RN}$ & $2,268(15)$ & $756(5)$ & $1,013(6.7)$ & $1,013(6.7)$ \\
\hline & LPN & $2,419.2(16)$ & $3,628.8(24)$ & $4,032(26.7)$ & $4,284(28.3)$ \\
\hline \multirow[t]{2}{*}{ Neonatal Intensive Care } & $\mathrm{RN}$ & $3,175.2(21)$ & $1,814.4(12)$ & $1,297.3(8.6)$ & $1,297.3(8.6)$ \\
\hline & LPN & $4,082.4(27)$ & $6,350.4(42)$ & $6,988.8(46.2)$ & $5,896.8(39)$ \\
\hline \multirow[t]{2}{*}{ Total } & RN & $18,144(120)$ & $11,491.2(76)$ & $8,450.6(55.9)$ & $7,789.8(51.5)$ \\
\hline & LPN & $27,669.6(183)$ & $34,776(230)$ & $38,349.6(253.6)$ & $39,166.7$ (259) \\
\hline
\end{tabular}

The nursing staff recommended by Cofen and at $\mathrm{MDH}$, Bench 1 and Bench 2 are shown in Table 3. The Pearson's chi-square test applied reveals that a significant difference in of the nursing staff exists for the three hospitals.

Table 3 - Proportions between RN and LPN staff at Cofen recommendation, MDH, Bench 1 and Bench 2

\begin{tabular}{|c|c|c|c|c|c|}
\hline Unit & Nursing Staff & Cofen Recomended & MDH Approved & Bench 1 & Bench 2 \\
\hline \multirow[t]{2}{*}{ Medical Surgical } & $\mathrm{RN}$ & $32.9 \%$ & $26.0 \%$ & $16.1 \% *$ & $16.6 \%$ * \\
\hline & LPN & $67.1 \%$ & $74.0 \%$ & $83.9 \% *$ & $83.4 \%$ * \\
\hline \multirow[t]{2}{*}{ Obstetric } & $\mathrm{RN}$ & $33.3 \%$ & $28.0 \%$ & $20.0 \%$ & $12.3 \%$ * \\
\hline & LPN & $66.7 \%$ & $72.0 \%$ & $80.0 \%$ & $87.7 \%$ * \\
\hline \multirow[t]{2}{*}{ Pediatric } & $\mathrm{RN}$ & $33.3 \%$ & $34.8 \%$ & $19.0 \%$ & $19.4 \%$ \\
\hline & LPN & $66.7 \%$ & $65.2 \%$ & $81.0 \%$ & $80.6 \%$ \\
\hline \multirow[t]{2}{*}{ Adult Intensive Care } & $\mathrm{RN}$ & $49.2 \%$ & $18.5 \% *$ & $19.2 \% *$ & $15.4 \%$ * \\
\hline & LPN & $50.8 \%$ & $81.5 \% *$ & $80.8 \% *$ & $84.6 \%$ * \\
\hline \multirow[t]{2}{*}{ Pediatric Intensive Care } & $\mathrm{RN}$ & $48.4 \%$ & $17.2^{*}$ & $20.1 \% *$ & $19.1 \% *$ \\
\hline & LPN & $51.6 \%$ & $82.8 \% *$ & $79.9 \% *$ & $80.9 \% *$ \\
\hline \multirow[t]{2}{*}{ Neonatal Intensive Care } & $\mathrm{RN}$ & $43.8 \%$ & $22.2 \% *$ & $15.7 \%$ * & $18.0 \% *$ \\
\hline & LPN & $56.3 \%$ & $77.8 \% *$ & $84.3 \% *$ & $82.0 \% *$ \\
\hline \multirow[t]{2}{*}{ Total } & $\mathrm{RN}$ & $39.6 \%$ & $24.8 \%{ }^{*}$ & $18.1 \%$ * & $16.6 \%$ * \\
\hline & LPN & $60.4 \%$ & $75.2 \%$ * & $81.9 \%$ * & $83.4 \%$ * \\
\hline
\end{tabular}

$* \mathrm{P}<.05$ when compared with Cofen recommendation

\section{Discussion}

The process we adopted to estimate the required nursing staff of a new hospital equipped us with strong arguments to justify the budget we considered necessary to establish the new nursing staff. 
Regarding the nursing staff approved by the MDH board, the total number of individuals in the staff was similar to the numbers suggested by Cofen and applied by Bench 1 and Bench 2. However, a significant difference $(p<0.05)$ was observed when comparing the nursing staff recommended by Cofen with that in each of these settings ( $\mathrm{MDH}$, Bench 1 , and Bench 2). This statistical difference is due to the presence of a reduced RN staff in the intensive care units in the three hospitals. In Bench 1, the reduced RN staff also occurs in the medical-surgical unit and, in Bench 2, the reduced RN staff occurs in all units except in the pediatric unit (Table 2).

Many authors ${ }^{(2-10)}$ reinforce the fact that, to provide high quality of care, it is necessary to have an appropriate number and adequate level of personnel in the nursing staff. However, in most cases, the definition of the budget for a new hospital does not rely on this assumption but rather on the benchmarking that is done considering supposedly similar institutions. Also, the fact that the government in Brazil aims at productivity rather than at quality may lead to some cuts in the established budget. This is invariably reflected in the LPN-RN ratio. Currently, we have a $3 / 1$ ratio at $\mathrm{MDH}$, whereas this ratio is 4.5/1 and 5/1 in Bench 1 and 2, respectively.

Almost a year after opening the doors of $\mathrm{MDH}$ we identified some important decisions the board made when planning the nursing staff and the whole structure of the hospital. For instance, the decision to have administrative personnel responsible for administrative tasks like answering the phone, organizing patient reports and performing patient registration, instead of using the nursing staff for these tasks, provided the latter with more time and availability for taking care of patients. Also, the fact that drugs and medications were sent to and from the pharmacy by a specific individual and not by someone on the nursing staff also diminished their administrative workload, allowing the nursing staff to focus more on patient care than on administrative tasks.

Nursing staff time spent on administrative tasks is an issue in many hospitals and institutions around the world(14,23). At $\mathrm{MDH}$, we were able to lower the time the nursing staff spends on administrative activities, although some administrative activities, such as filling out specific documentation or patient information, are still their responsibility. Better identification of what these tasks are may allow us to execute further changes that will provide nursing staff with even more time dedicated to patient care.
The fact that medical-surgical, pediatric, and obstetric units, such as intensive care units, are located on the same floor allowed some flexibility to the nursing staff allocated to work on those floors. They are able to circulate among units and provide extra help when necessary, considering the specific skills and knowledge of each professional. The psychiatric unit was not included in this study because we could not find any similar institution to compare the nursing staff with.

Now that one year has passed since we opened doors, we realize some of the things we could have done differently. For instance, our hospital is located in an extremely violent area where death of young and healthy adults is a common event. At the time we did not realize that this could represent a scenario for organ donation and did not make specific investments in this respect. However, new efforts and investments aiming at organ donation may still be justified.

\section{Conclusion}

Although many differences exist between Brazil and other countries concerning health care facilities, we believe that our experience in estimating the nursing staff for the new hospital will be useful to other health care managers and administrators who are involved with similar tasks, regardless of hospital size and location. Also, we agree that almost one year after $\mathrm{MDH}$ has opened it is necessary to review nursing staff hours with the current data to reinforce expenditure for these personnel.

\section{References}

1. Filerman GL. Health: the emerging context of management. In: Taylor RJ, Taylor SB. The AUPHA Manual of Health Services Management. Gaithersburg (MD): Aspen Publishers; 1994. p. 3-17.

2. Needleman J, Buerhaus $P$, Mattke $S$, Stewart $M$, Zelevinsky K. Nurse-staffing levels and the quality of care in hospitals. N Engl J Med. 2002;346(22):1715-22.

3. Jackson M, Chiarello LA, Gaynes RP, Gerberding JL. Nurse staffing and healthcare-associated infections: proceedings from a working group meeting. Am J Infect Control. 2002;30(4):199-206.

4. American Nurses Association. Nurse Staffing and Patient Outcomes in the Inpatient Hospital Setting. Washington (DC): American Nurses Association; 2000.

5. Kovner C, Gergen PJ. Nurse staffing levels and adverse events following surgery in US hospitals. Image J Nurs Sch. $1998 ; 30(4): 315-21$. 
6. Ainken LH, Clarke SP, Sloane DM. Hospital staffing, organization, and quality of care: cross-national findings. Intl J Qual Heath Care. 2002;14(1):5-13.

7. Lichtig LK, Knauf RA, Milholland DK. Some impacts of nursing on acute care hospital outcomes. J Nurs Adm. 1999;29(2):25-33.

8. Flood SD, Diers D. Nurse staffing, patient outcome and cost. Nurs Manage. 1988;19(5):34-43.

9. Blegen MA, Goode CJ, Reed L. Nurse staffing and patient outcomes. Nurs Res. 1998;47(1):43-50.

10. Giraud T, Dhainaut J, Vaxelaire J, Joseph T, Journois $D$, Bleichner $G$, et al. Iatrogenic complications in adult intensive care units: a prospective two-center study. Crit Care Med. 1993;21(1):40-51.

11. American Hospital Association. Cost of caring: key drivers of growth in spending on hospital care [internet]. 2003 Feb. [cited 2010 Apr 1]. Available from: http:// www.aha.org/aha/content/2003/pdf/PwCcostsReport.pdf 12. Institute of Medicine. Nursing staff in hospitals and nursing homes. Is it adequate? Washington (DC): National Academy Press; 1996. Staffing and Workrelated Injuries and Stress; p. 169-88.

13. Agency for Healthcare Research and Quality. Hospital nurse staffing and quality of care. Rockville (MD): AHRQ; 2004. Research in Action, n14.

14. Beglinger JE. A critical competency: determining and communicating the number of nurses you must hire. Nurs Econ. 2007;25(3):174-7.

15. Gaidzinski RR. O dimensionamento de pessoal de enfermagem em instituições hospitalares [tese]. São Paulo (SP): Escola de Enfermagem da Universidade de São Paulo; 1998. 126 p.

16. Conselho Federal de Enfermagem (COFEN). Resolução n. 293 de setembro de 2004. Fixa e estabelece parâmetros para dimensionamento do quadro de profissionais de enfermagem nas instituições de saúde e assemelhados [internet]. 21 set 2004. [acesso $01 \mathrm{abr}$ 2010]. Disponível em: http://www.coren-sp.gov.br/ drupal6/node/3538

17. Hurst $\mathrm{K}$, editor. Selecting and applying methods for estimating the size and mix of nursing teams [internet]. Leeds, West Workshire (UK): Nuffield Institute for Health; 2003. [cited 2010 Feb 20]. Available from: http://www. who.int/hrh/tools/size_mix.pdf

18. Antunes AV, Costa MN. Dimensionamento de pessoal de enfermagem em um hospital universitário. Rev. Latino-Am. Enfermagem. 2003;11(6):832-9.

19. Fugulin FMT, Gaidzinski RR, Kurcgant P. Sistema de classificação de pacientes: identificação do perfil assistencial dos pacientes das unidades de internação do HU-USP. Rev. Latino-Am. Enfermagem. $2005 ; 13(1): 72-8$.
20. Prefeitura da Cidade de São Paulo [internet]. São Paulo. [acesso 20 nov 2009]. Disponível em: http:// www.prefeitura.sp.gov.br/cidade/secretarias/upload/ saude/arquivos/organizacao/Unid_Munic_Saude_Subp pdf

21. Observatório Cidadão Nossa São Paulo [internet]. São Paulo. [acesso 20 set 2009]. Disponível em: http:// www.nossasaopaulo.org.br/observatorio/regioes.php?r egiao $=27 \&$ distrito $=0$ \&tema $=10$

22. Covey SR. A whole new mind-set on fighting crime. The Police Chief [internet] 2008. [cited 2010 Feb 10]. Available from: http://policechiefmagazine. org/magazine/index.cfm?fuseaction=display\&article id $=1687$ \&issue_id $=122008$

23. Chaboyer W, Wallis M, Duffield C, Courtney M, Seaton P, Holzhauser K, et al. A comparison of activities undertaken by enrolled and registered nurses on medical wards in Australia: an observational study. Int J Nurs Stud. 2008;45(9):1274-84.
Received: Apr. $2^{\text {nd }} 2010$ Accepted: Sep. $17^{\text {th }} 2010$ 